\title{
Risks of reformulation: French patients complain after Merck modifies levothyroxine pills
}

The details of the lawsuits described in the box in this article (BMJ 2018;360:k714, doi:10.1136/bmj.k714) were incorrect. Vivre sans thyroîde has asked the law firm MySMARTcab to seek an "emergency expertise procedure," which will be heard in Paris on 23 February. MySMARTcab has already filed the civil claim for compensation against Merck. The case will be heard in Lyon on 1 October 2018. 